\title{
Is the microcosm approach using meiofauna community descriptors a suitable tool for ecotoxicological studies?
}

\author{
Anna Carolina Chaaban Santos ${ }^{\mathrm{a}, \mathrm{b}}$, Rodrigo Brasil Choueri ${ }^{\mathrm{c}}$, \\ Guacira de Figueiredo Eufrasio Pauly ${ }^{\mathrm{d}}$, Denis Abessa ${ }^{\mathrm{d}}$, Fabiane Gallucci ${ }^{\mathrm{c}, *}$ \\ a Centro de Estudos do Mar da Universidade Federal do Paraná, Av. Beira-mar, s/n 83255-976, Pontal do Sul, PR, Brazil \\ b Centro de Biologia Marinha da Universidade de São Paulo, Rodovia Manoel Hypólito do Rego, km 131.5, São Sebastião, SP 11600-000, Brazil \\ ${ }^{c}$ Instituto do Mar da Universidade Federal de São Paulo, Rua Carvalho de Mendonça, 144, Santos, SP CEP: 11070-100, Brazil \\ ' Universidade Estadual Paulista, Campus do Litoral Paulista, Praça Infante Dom Henrique, s/n, São Vicente-Vicente, SP 11330-900, Brazil
}

\section{A R T I C L E I N F O}

\section{Keywords:}

Meiofauna

Microcosm

Community assessment

Benthos

Sediment toxicity

Sewage

\begin{abstract}
A B S T R A C T
The usual approaches used in ecological risk assessment have been based on individual and population level standard procedures. Although these have been important tools to assess adverse effects on ecosystems, they are generally simplified and therefore lack ecological realism. Microcosm studies using meiobenthic communities offer a good compromise between the complexity of the ecosystem and the often highly artificial settings of laboratory experiments. An experiment was designed to investigate the potential of the microcosm approach using meiofauna as a tool for ecotoxicological studies. The experiment tested the ecological effects of exposure to sewage-impacted pore water simultaneously at the community level using meiofauna microcosms and at the individual level using laboratory fecundity tests with the copepod Nitokra sp. Specifically, the experiment tested the toxicity of pore water from three sites according to a contamination gradient. Both approaches were efficient in detecting differences in toxicity between the less and more contaminated sites. However, only multivariate data from community analysis detected differences in the gradient of contamination. In addition to information about toxicity, the community level microcosm experiment gave indications about sensitive and tolerant species, indirect ecological effects, as well as raised hypothesis about contamination routes and bioavailability to be tested. Considering the importance of meiofauna for benthic ecosystems, the microcosm approach using natural meiobenthic communities might be a valuable addition as a higher tier approach in ecological risk assessment, providing highly relevant ecological information on the toxicity of contaminated sediments.
\end{abstract}

\section{Introduction}

Marine ecotoxicological studies have traditionally used individual and population level parameters by means of single "indicator" species tests as a standard approach to predict the biological effects of a particular chemical and identify how dangerous it could be by showing a specific response (Chapman, 2002; Vighi and Villa, 2013). Studies at these levels of biological organization have the advantage of monitoring lethal and sublethal effects so that environmental damage may be controlled before causing dramatic consequences to the ecosystem (e.g. loss of species, disturbances on ecosystem functions). However, they have the disadvantages of being species specific and eventually the biological response of the selected model species won't necessarily promote a cascade effect through the upper levels of biological organization (Kimball and Levin, 1985; Vighi and Villa, 2013). In addition, single-species tests exclude the interactions and indirect effects that regulate biological communities which difficults the extrapolation to field conditions. Considering the preservation of ecosystems as the main aim of environmental conservation, understanding how contaminants affect high levels of biological organization considering the complexity of the ecosystems is of foremost importance for more realistic ecological risk assessments.

Microcosm tests using natural communities offer a good compromise between the complexity of the ecosystem and the often highly artificial settings of laboratory experiments (Rohr et al., 2016; Van den Brink et al., 2005). In addition to being more representative by considering the entire community with many species with different life traits and sensitivities, the microcosm approach preserves species interactions and considers the physico-chemical environment as well as different exposure routes. In this way, biotic and abiotic interactions characteristic of natural conditions are allowed to mediate the outcome of the toxicity test (Rohr et al., 2016). Therefore, community-based

\footnotetext{
* Corresponding author.

E-mail address: fgallucci@unifesp.br (F. Gallucci).
} 
microcosm tests are usually more ecologically relevant than singlespecies tests and represent a potentially powerful tool for improving ecological realism of risk assessment (Cairns and Pratt, 1993; Chapman, 2002; Schratzberger et al., 2002; SCENIHR, SCCS and SCHER, 2013; Höss et al., 2014).

Marine sediments are sinks for large numbers and amounts of anthropogenic substances that enter the marine environment, which may exert toxic effects on the benthic biota. The use of the single-species toxicity tests is of particular concern in the assessment of the sedimentary environment which is highly complex and biodiverse. In addition, benthic organisms used in such tests are often restricted to specific habitats and not very representative in marine sediments. This is why the importance of integrating multiple lines of evidence in sediment quality assessments, including the benthos, has long been recognized (Carr et al., 1996; Chapman and Hollert, 2006; Choueri et al., 2010; Krull et al., 2014; Long and Chapman, 1985).

Within sedimentary environments, meiofauna communities comprise the most abundant and species-rich metazoans (Coomans, 2000; Heip et al., 1985; Lambshead and Boucher, 2003). They are ubiquitous in virtually all marine and estuarine environments and due to rapid generation time and fast metabolic rates, they play significant roles in the provision of energy to higher trophic levels (Woodward, 2010). They also significantly contribute to important ecosystem functions such as decomposition and nutrient recycling processes (Bonaglia et al., 2014; Hubas et al., 2010). Despite their ecological importance, this group represents an often neglected component of ecotoxicological studies. Intriguingly, however, is that meiofauna communities are particularly well-suited to microcosm studies. Due to the general lack of planktonic larvae, the manipulation and maintenance of natural communities in laboratory microcosms is relatively simple (Austen and McEvoy, 1997, Austen and Sommerfield, 1997, Schatzberger et al., 2000, Millward et al., 2004). Microcosms holding less than $200 \mathrm{~g}$ of sediment typically contain many thousands of individuals and up to several dozen of species belonging to different trophic levels (e.g. bacterivores, microvores, herbivores, omnivores, and predators). In the last decades, the development of such microcosm setups have allowed the investigation of the isolated effects of different pollutants in natural communities under controlled and reproducible conditions (Austen et al., 1994; Gallucci et al., 2015; Schratzberger et al., 2000).

The aim of the present study was to evaluate the suitability of using meiofauna microcosm assays to assess marine sediment quality. This was done through the exposure of a meiobenthic natural community to sewage impacted pore-water and comparison of the responses of community structure with (i) effects observed by a single-species fecundity test with the meiobenthic copepod Nitokra sp. reared in the laboratory and (ii) sediment chemistry data. Adverse effects of sewage contaminated water have already been reported as a result from significant concentrations of pharmaceuticals and personal care products - PPCPs (Bila and Dezotti, 2003; Rodgers-Gray et al., 2000; Shareef et al., 2008), trace elements (Tjandraatmadja et al., 2008), surfactants (Jensen, 2004) and hydrocarbons (Jensen and Sverdrup, 2002). Therefore, we expected to find lower fecundity rates and changes in community structure as a response to pollutants present in the extracted pore water. The experiment evaluated the response of the different endpoints in two different time periods. We expected to see direct toxic effects in the short-term (7 days) and a result of direct and indirect effects on the longer term (30 days).

\section{Methods}

\subsection{Experimental design}

A microcosm experiment was designed to assess the effects of exposure to sewage-impacted pore water on the fecundity of the meiobenthic copepod Nitokra sp. reared in the laboratory and on the structure of a meiobenthic community. Defaunated sediments from a reference site were individually contaminated with pore water from sediments collected at three sites located at different distances from the sewage outfall located at Araçá Bay, Brazil (Suppl. Fig. 1). The sites were selected based on previous data from a field investigation (Gallucci et al., unpublished data) that established regions affected by an inverse gradient of distance from the outfall, i.e., the further the more contaminated (within a radius of $150 \mathrm{~m}$ ), due to the major deposition at distant points (Suppl. Table 1). Sediments contaminated with pore water were used for microcosm set ups designed for the analysis of meiobenthic communities and for the set up of individual bioassays for the analysis of Nitokra sp. fecundity.

\subsection{Sediment collection and defaunation}

Sediments used in the microcosm experiment were collected at the shallow subtidal zone (ca. $1 \mathrm{~m}$ ) of a sandy beach located at São Sebastião Channel, on the coast of São Paulo, southeastern Brazil $\left(23^{\circ}\right.$ 49. $58^{\prime} \mathrm{S}, 45^{\circ} 25$. $31^{\prime} \mathrm{W}$ ). This was considered as a reference site because it is a "zone of special management" in the marine spatial zoning of the APA Marinha Litoral Norte (North Shore Marine Protected Area). Sediment sampling and defaunation followed Gallucci et al. (2015). Another sampling was performed at the same site fifty days later to obtain sediment containing meiofauna (first $5 \mathrm{~cm}$ layer) to set the experiments (see Section 2.4). These sediments were transferred to boxes and slightly mixed to ensure an even distribution of the meiofauna among microcosms.

\subsection{Extraction of pore water and contamination}

The sediments used for the extraction of pore water were collected at the three sites (Suppl. Fig. 1) using a Van Veen grab sampler and were taken to the lab where they were gently homogenized and stored in plastic bags at a refrigerator $\left(8^{\circ} \mathrm{C}\right)$ until extraction (approximately $3 \mathrm{~h}$ after collection). The extraction was done by centrifugation of ca. $130 \mathrm{~g}$ of sediment at $400 \mathrm{rpm}$, for $20 \mathrm{~min}$ (Rachid, 2002) in a refrigerated room $\left(20^{\circ} \mathrm{C}\right)$. The process was repeated until the required amount $(500 \mathrm{~mL})$ was available. The extract obtained was kept in the refrigerator $\left(8^{\circ} \mathrm{C}\right)$ for a few hours. Redox potential and temperature were measured before and after each step and the variations followed the accepted standard for toxicity testing (Environmental Protection Agency, 2001). The contamination occurred through the saturation of the defaunated sediments with the extracted pore water, i.e. $35 \mathrm{~mL}$ of pore water for each $67 \mathrm{~g}$ of sediment.

\subsection{Microcosm essays}

\subsubsection{Microcosm set up}

Microcosms consisted of $500 \mathrm{~mL}$ Beakers $(12 \times 9 \mathrm{~cm})$ filled with $4 \mathrm{~cm}$ sediment layers (spiked sediments + sediments containing meiofauna) covered with $350 \mathrm{~mL}$ of filtered seawater (equivalent to an $8 \mathrm{~cm}$ layer). The microcosms were constantly aerated and covered by parafilm to prevent evaporation and salinity increase. Microcosms were randomly assigned on the bench and maintained under constant temperature $\left(20^{\circ} \mathrm{C}\right)$ and dark conditions to reduce microalgal growth (Schratzberger et al., 2002) and photodegradation of any pollutants.

\subsubsection{Sampling of microcosms}

Four replicates of each microcosm treatment (sites 1, 2 and 3) were randomly sampled at time intervals of 5, 15 and 30 days (T5, T15 and T30). The overlying water was first removed and the redox potential measured at the sediment surface (ca. $1 \mathrm{~cm}$ depth) using an electrode connected to Hanna Instruments HI $991003 \mathrm{~m}$. Then, $3 \mathrm{~cm}^{3}$ of sediment were sampled for the analysis of chlorophyll $a$ and pheopigments concentrations as a proxy of the microphytobenthos biomass and $2 \mathrm{~cm}^{3}$ were sampled for Nitokra sp. fecundity tests. The remaining sediment was fixed with formaldehyde $4 \%$ for analysis of meiofauna (meiofaunal 
taxa and nematode morphospecies). Sediments from one replicate microcosm from each treatment were sampled at the beginning (T0) and end (T30) of the experiment for determination of the concentrations of total ammonia, total organic carbon, total nitrogen, phosphorus, arsenic, cadmium, lead, copper, chrome, mercury, nickel, zinc and surfactants.

\subsubsection{Sample processing}

Meiofauna samples were washed through a $45 \mu \mathrm{M}$ mesh sieve and extracted by flotation with Ludox TM 50 (specific density 1.18) (Heip et al., 1985). The retained material was stored in formaldehyde $4 \%$ and stained with Rose Bengal. Meiofauna was counted and identified under a stereomicroscope. Ten percent of the nematodes per microcosm were randomly picked, evaporated slowly in anhydrous glycerol and mounted on permanent slides for identification. A lowest and highest limit of 100 and 250 nematodes were established (i.e. when the total of nematodes was lower than 100, all individuals were picked for identification and when the total was higher than 250, only 250 individuals were taken). Nematodes were identified to genus level (Warwick et al., 1998) and further separated into morphospecies. Microphytobenthic samples were immediately frozen $\left(-20^{\circ} \mathrm{C}\right)$ and photosynthetic pigments extracted with $10 \mathrm{~mL}$ of $90 \%$ acetone for $24 \mathrm{~h}$ at a temperature of $4{ }^{\circ} \mathrm{C}$. Pigments were analyzed from absorbance spectra at $665 \mathrm{~nm}$ and $750 \mathrm{~nm}$ before and after acidification with HCL through a digital spectrophotometer. Concentrations of pigments were estimated using the equations of Lorenzen (1967).

The determination of chemical concentrations was done according to standard methods. For the quantification of arsenic, cadmium, lead, copper, chrome, nickel and zinc, sediments were acid-digested according to the method 3050B of Environmental Protection Agency (1996) and analyzed by Inductively Coupled Plasma-Atomic Emission Spectrometry (ICP-AES) (Environmental Protection Agency, 2007a). Mercury was tested by Cold-Vapor Technique (Environmental Protection Agency, 2007b), ammonia by selective electrode (Standard Methods Online, 1992), phosphorus with ascorbic-acid method, nonionic surfactants as cobalt thiocyanate active substances (CTAS) (Standard Methods, 2005), total nitrogen with determination by electrode ion selective and total organic carbon with oxidation of organic matter wet method with potassium dichromate in sulfuric acid medium (EMBRAPA, 1997). Spiked sample and blanks analyses were performed for the quality control of the chemical analyses. Recovery rates ranged from $80 \%$ to $120 \%$.

\subsection{Nitokra sp. assay}

Nitokra sp. bioassays were performed using $2 \mathrm{~cm}^{3}$ of the contaminated sediments just after contamination (T0), and after 15 and 30 days of incubation in meiofauna community microcosms (T15 and T30). The bioassay was conducted by adding $7,5 \mathrm{~mL}$ of water with adjusted salinity of 27-2 $g$ of the sampled sediment. Toxicity was tested by adding 5 gravid females to each replicate (modified from Lotufo and Abessa (2002)). Four replicates were done for each treatment (sites 1, 2 and 3) and exposure period (T0, T15 and T30). The system was maintained at $25{ }^{\circ} \mathrm{C} \pm 2$ temperature and a $16 \mathrm{~h}: 8 \mathrm{~h}$ light: dark photoperiod, during 7 days. Each sample was fixed with $1.5 \mathrm{~mL}$ of formaldehyde $10 \%$ and stained with Bengal Rose.

Samples were washed in a mesh of $45 \mu \mathrm{m}$ to quantify the nauplii, copepodites, and adult females in a stereomicroscope. The fecundity rate of Nitokra sp. was determined through the reason $(\mathrm{N}+\mathrm{C}) / \mathrm{F}$, where $\mathrm{N}, \mathrm{C}$ and $\mathrm{F}$ are the number of nauplii, copepodites and adult females respectively. A reference test was also performed to assess the organisms' sensitivity from a common batch, to assure that organisms would respond properly, not presenting a false positive result. Concentrations at $0.1 ; 1.0 ; 5.0 ; 10.0 ; 20.0$ and $50.0 \mathrm{mg} / \mathrm{L}$ of potassium dichromate $\left(\mathrm{K}_{2} \mathrm{Cr}_{2} \mathrm{O}_{2}\right)$ were used as reference positive control for this test. Five gravid females were placed and counted daily for mortality until complete exposure time. The lethal concentration for $50 \%$ of the organisms after $96 \mathrm{~h}$ exposure $\left(\mathrm{LC}_{50}-96 \mathrm{~h}\right)$ was determined and compared to the control chart of the laboratory.

\subsection{Statistical analyses}

Significance of differences in meiofaunal univariate measures and fecundity of Nitokra $s p$. were tested by permutational multivariate analysis of variance (PERMANOVA; Anderson, 2001). The analysis tested two factors: "Treatment" (3 levels: Sites 1, 2 and 3) and "Exposure period" (5, 15 and 30 days) as fixed factors. The same factors were used to assess significant differences in multivariate structure of nematode assemblages. The multivariate structure of the meiofauna and nematode assemblages was visualized by performing a non-metric multi-dimensional scaling ordination (nMDS) (Clarke and Ainsworth, 1993). PERMANOVA tests were conducted on Euclidean distance matrices, which is recommended for microcosm experiments because as a closed system it does not have the income of new species and because our hypothesis considers that some species can disappear due to the toxicity (Anderson et al., 2011). Pairwise a posteriori multiple comparisons tests were performed when significant differences were detected $(\mathrm{p}<0.05)$. The residuals were permutated using unrestricted permutation of raw data.

Similarity percentages programme (SIMPER) was used to determine the contribution of individual morphospecies to the average dissimilarity between treatments and/ or exposure period. To check if there were any specific feeding types of nematodes affected by the exposure to contaminated sediments, nematode species were assigned to feeding types according to Wieser's (1953) classification based on the morphology of the buccal cavity: selective deposit feeders (1A), non-selective deposit feeders (1B), epigrowth feeders (2A) and predator/omnivores (2B) and the percentage of contribution of each feeding type to the total abundance of nematodes was calculated for each sample.

The associations among the variables measured in the current study were assessed by factor analysis with factor extraction by principal component analysis (FA/PCA). The analysis was conducted with varimax normalised rotation of the dataset. Autoscaled variables of meiofauna community descriptors (total abundance of nematodes and copepods, nematode species richness (S), evenness $\left(\mathrm{J}^{\prime}\right)$ and ShannonWiener diversity $\left(\mathrm{H}^{\prime}\right)$ and abundances of the taxa Sabatieria sp.1, Oncholaimellus sp.1, Pseudosteineria sp.1, Nudora sp.1 and Dichromadora sp.1), Nitokra sp. fecundity, microphytobenthic parameters (concentrations of chlorophyll $a$ and pheopigments), and sediment chemical parameters (redox potential, total organic carbon contents, levels of total ammonia and nitrogen, $\mathrm{As}, \mathrm{Cd}, \mathrm{Cu}, \mathrm{Cr}, \mathrm{Hg}, \mathrm{Ni}, \mathrm{Pb}, \mathrm{Zn}$ and LAS) measured at the beginning and at the end of the microcosm assays were assessed for multivariate associations. Only factors accounting for at least $10 \%$ of explanation of the total variance were analyzed. The loading cut-off was set at $|0.38|$. Factor scores were estimated in order to assess the relevance of the factors to each of the 24 cases.

All univariate and multivariate analysis were performed using the software PRIMER ${ }^{\circ}$ (version 6) (Clarke and Gorley, 2006) with the additional add-on package PERMANOVA (Anderson et al., 2008) and STATISTICA $^{\circ}$ (version 12StatSoft).

\section{Results}

\subsection{Environmental data}

Chlorophyll- $a$ and pheopigment concentrations varied from 0.305 to 0.556 and from 0.04 to $0.25 \mu \mathrm{g} \mathrm{cm}^{-3}$, respectively. There were no significant differences between treatments or exposure periods (PERMANOVA $\mathrm{p}>0.05$ ). Redox potential measures varied from -34 to $53 \mathrm{mV}$ and differed between treatments depending on the time of exposure (significant interaction effect between "exposure period" and "treatment"). Those differences were, nevertheless, not associated to 
meiofauna descriptors and Nitokra fecundity (item 3.4). Total ammonia and organic carbon increased in all stations over the time of exposure.

Station 1 showed the lowest concentrations of metals (except for mercury) and surfactants when compared to stations 2 and 3, although the differences were small among all stations (Suppl. Table 2). In general, levels of metals and As were low in all stations, with few exceptions. Cd levels exceeded the Threshold Effects Level (TEL) set by CCME (2001) at all stations and Hg was equal to TEL at station 1. In comparison to sediment quality guidelines developed by Brazilian Southeastern estuaries (Paranaguá and Santos estuarine systems) (Choueri et al., 2009), besides Cd and Hg exceedances (in agreement to the CCME, 2001 guidelines), As (at all stations) and $\mathrm{Ni}$ (at station 3) were found at moderate levels. However, as it will be discussed further, only $\mathrm{Cd}$ and $\mathrm{Ni}$ were negatively associated to meiofauna community descriptors and Nitokra sp. fecundity (Section 3.4).

\subsection{Meiofauna community}

The meiofauna was represented by 9 higher taxa with densities ranging from 38 to 2501 individuals per microcosm. Nematodes numerically dominated all samples, representing from $60 \%$ to $100 \%$ of the total metazoan meiofauna per microcosm, and exhibited a total of 49 morphospecies belonging to 41 genera. Densities ranged from 28 to 2350 individuals per microcosm. Copepods were the second most abundant group $0-33 \%$ of total meiofauna) with densities ranging from 0 to 278 individuals per microcosm.

Nematode and copepod abundances were significantly different between treatments, independently of the duration of exposure (Table 1). In accordance to the contamination gradient, abundances of both groups decreased from site 1 towards sites 2 and 3 (Fig. 1). Posthoc analysis confirmed significantly lower nematode abundances at sites 2 and 3 when compared to site 1. Copepod abundances did not differ between sites 1 and 2, and were significantly lower at site 3 .

Table 1

Results from two-way PERMANOVA analysis for meiobenthic univariate indices, Nitokra sp. fecundity and multivariate structure of nematode assemblages. $\mathrm{EP}=$ Exposure period and Treat $=$ Treatment. Values in bold represent $\mathrm{p}<0.05$.

\begin{tabular}{|c|c|c|c|c|c|}
\hline & $d f$ & MS & Pseudo-F & $P$ (perm) & Unique perms \\
\hline \multicolumn{6}{|c|}{ Nematode density } \\
\hline Treatment & 2 & $1,224 \mathrm{E} 6$ & 7,7314 & 0,004 & 999 \\
\hline Exposure period & 2 & $1,7756 \mathrm{E} 6$ & 11,212 & 0,001 & 997 \\
\hline $\mathrm{EP} \times$ Treat & 4 & $1,3139 \mathrm{E} 5$ & 0,82971 & 0,538 & 998 \\
\hline Residue & 27 & $1,5836 \mathrm{E} 5$ & & & \\
\hline Total & 35 & & & & \\
\hline \multicolumn{6}{|l|}{ Copepod density } \\
\hline Treatment & 2 & 25489 & 8,9419 & 0,002 & 998 \\
\hline Exposure period & 2 & 13235 & 4,643 & 0,018 & 997 \\
\hline $\mathrm{EP} \times$ Treat & 4 & 4083,8 & 1,4327 & 0,231 & 999 \\
\hline Residue & 27 & 2850,5 & & & \\
\hline Total & 35 & & & & \\
\hline \multicolumn{6}{|c|}{ Nitokra sp.fecundity } \\
\hline Treatment & 2 & 166,55 & 3,4406 & 0,046 & 998 \\
\hline Exposure period & 2 & 453,99 & 9,3783 & 0,002 & 998 \\
\hline $\mathrm{EP} \times$ Treat & 4 & 68,104 & 1,4069 & 0,258 & 999 \\
\hline Residue & 27 & 48,408 & & & \\
\hline Total & 35 & & & & \\
\hline \multicolumn{6}{|c|}{$N^{\circ}$ of nematode species } \\
\hline Treatment & 2 & 27,444 & 3,0811 & 0,068 & 997 \\
\hline Exposure period & 2 & 101,69 & 11,417 & 0,001 & 999 \\
\hline $\mathrm{EP} \times$ Treat & 4 & 9,6944 & 1,0884 & 0,377 & 998 \\
\hline Residue & 27 & 8,9074 & & & \\
\hline Total & 35 & & & & \\
\hline \multicolumn{6}{|c|}{ Nematode assemblage } \\
\hline Treatment & 2 & 3,0207E5 & 8,0805 & 0,001 & 999 \\
\hline Exposure period & 2 & $2,2861 \mathrm{E} 5$ & 6,1153 & 0,003 & 999 \\
\hline $\mathrm{EP} \times$ Treat & 4 & 39344 & 1,0525 & 0,409 & 998 \\
\hline Residue & 27 & 37383 & & & \\
\hline Total & 35 & & & & \\
\hline
\end{tabular}

Nematode species richness and diversity did not differ between treatments (Table 1). Nematode and copepod abundances and nematode species richness also decreased over time, being significantly lower after 15 days of exposure, independently of the treatment (Table 1 , Fig. 2). Nematode densities and species richness remained significantly lower after 30 days of exposure when compared to 5 days (Fig. 2).

As for the univariate measures, PERMANOVA analysis for the multivariate structure of nematode assemblages revealed significant differences in assemblage structure between treatments and between exposure periods, with no significant interaction between the two factors (Table 1). Post-hoc analysis revealed significant differences between the three sites and the two exposure periods (Suppl. Table 3). Fig. 3 shows the MDS ordination for nematode assemblage structure for treatments. Although there is not a clear distinction between sites, there was a greater overlap between Sts 1 and 2 with a greater separation of St. 3. Indeed, SIMPER analysis revealed a greater distance between Sites 1 and 3 (average distance: 197129) with St. 2 at an intermediate position (average distances of St. 2 with St. 1 and 3: 148867,68 and 76696,12 , respectively), confirming a pattern that agrees with the contamination gradient. According to SIMPER analysis, differences between treatments were mainly due to lower densities of the most abundant species (i.e., Nudora sp. 1, Pseudosteineria sp. 1 and Dichromadora sp.1) in St. 2 and 3 when compared to St. 1, with higher magnitude of differences in average abundances at St. 3. It also pointed for the lower abundances of Oncholaimellus sp.1, a predator who was not particularly abundant, in Sts 2 and 3 compared to St 1 . Station 3 also differed from both St. 1 and 2 by showing an increase in the average abundance of the species Sabatieria sp.1.

There were also significant differences in nematode assemblage structure between exposure periods independently of the treatment (Table 1). Assemblages were significantly different at both 15 and 30 days of exposure when compared to day 5 (Suppl. Table 3). Simper analysis indicated that differences were due to lower abundances of the most abundant species (i.e., Nudora sp. 1, Pseudosteineria sp. 1 and Dichromadora sp.1) after 15 and 30 days.

In this study, all feeding types of nematodes (1A: selective deposit feeders, 1B: non-selective deposit feeders, 2A: epigrowth feeders and 2B: predator/omnivores) were represented in all treatments. Significant differences between treatments were detected for the densities of the groups of epigrowth feeders (2A) and predators (2B) (Table 2), which were both significantly lower in Sts 2 and 3 compared to St. 1 (post-hoc $\mathrm{p}<0.05)$.

\subsection{Nitokra sp. fecundity test}

Similar to meiofauna measures in the microcosm setup, Nitokra sp. fecundity showed significant differences between treatments and between exposure periods, with no interaction between the two factors (Table 1). As for nematodes, number of nauplii and copepodite per female was significantly lower at sites 2 and 3 compared to site 1 , independently of exposure period (Fig. 1). Also in agreement with meiofauna results, toxicity as measured by Nitokra sp. fecundity was significantly higher (i.e. fecundity significantly lower) after 15 days of contamination (Fig. 2). Results from the reference test were considered acceptable (i.e. within the limits of the control chart of the laboratory ( $2 \times$ the standard deviation), with a $\mathrm{LC}_{50}-96 \mathrm{~h}$ of $13.89 \mathrm{mg} / \mathrm{L}$ of potassium dichromate.

\subsection{Multivariate relationships between variables}

Three factors were extracted from the original dataset which together accounted for $69.3 \%$ of the total explained variance (Table 3 ). The first factor (F1, which explained $41.69 \%$ of the variance) showed meiobenthic community descriptors ( $\mathrm{S}$, total abundance of nematodes and copepods, abundances of Oncholaimellus sp.1, Nudora sp.1, Dichromadora sp.1 and Pseudosteineria sp.1) and Nitokra sp. fecundity 

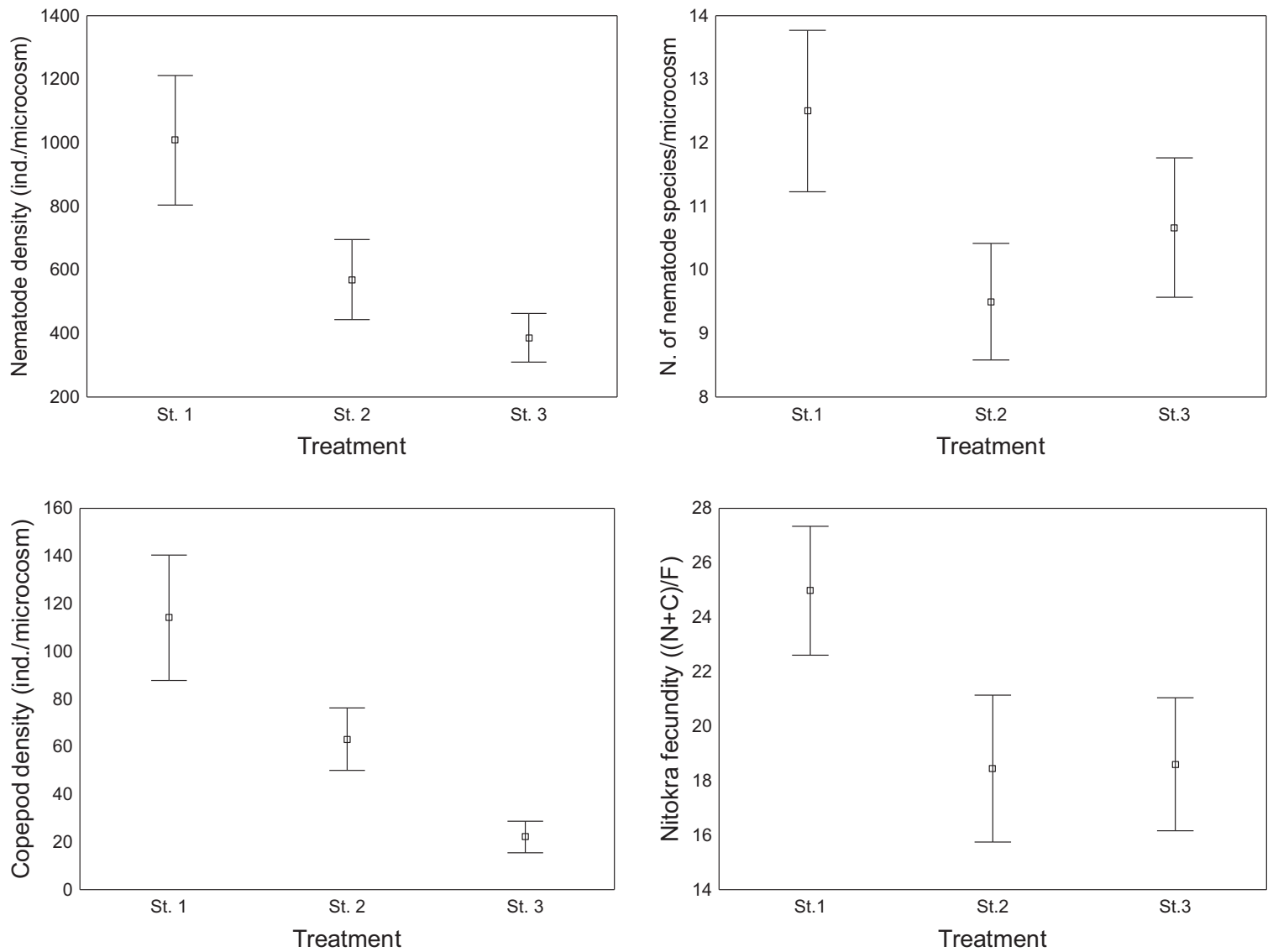

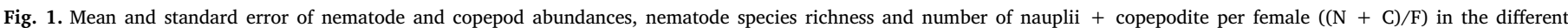
treatments.

negatively associated with levels of chemicals in the sediments (total ammonia, LAS, and all metals except $\mathrm{Hg}$ ). The second factor (F2, which contributed with $16.8 \%$ of the explained variance) showed the association of levels of pheopigments, total ammonia, total nitrogen, TOC, and some metals ( $\mathrm{Cd}, \mathrm{Cu}, \mathrm{Ni}$ and $\mathrm{Zn}$ ). This group was negatively associated with potential redox and As concentrations. The third factor (F3, which explained $10.95 \%$ of the total variance) showed the association of $\mathrm{S}, \mathrm{J}^{\prime}, \mathrm{H}^{\prime}$, abundance of Sabatieria sp.1 and pheopigment concentrations. Levels of chlorophyll $a$ were negatively associated with these variables.

Factor scores are shown in Fig. 4. F1 scores exhibited notable differences among treatments (sites). Site1 showed negative scores at both $\mathrm{T} 1$ and $\mathrm{T} 3$ for almost all replicates (except one replicate showing score close to 0 ), site 2 showed negative scores at $\mathrm{T} 1$ and positive scores at $\mathrm{T} 3$, and site 3 showed positive scores for F1 both at T1 and T3. F2 scores, in turn, showed remarkable differences between times of exposure. Sites 1, 2, and 3 showed positive scores for F2 at T1 and negative scores at T3. The scores estimated for F3 showed some differences among replicates within the same treatments. High positive scores for F3 were estimated for site 3 consistently at T1, and also for some replicates of site 1 both at T1 and T3. Negative scores for F3 were estimated consistently for site 2 at T1, but the lowest values were estimated for some replicates of site 3 at T3.

\section{Discussion}

Multivariate relationships between variables indicated a clear relationship between Nitokra sp. fecundity and meiofauna community parameters. Both endpoints were negatively related with chemical concentrations indicating an effect of the contaminant sources on both test-organisms. Since only a few contaminants are apparently contributing to the observed effects, i.e. associated with effects in the FA/PCA and/or at a concentration above the threshold effects level (TEL) (CCME, 2001) or Brazilian sediment quality guidelines (Choueri et al., 2009), the observed association of contaminants levels and individual and ecological responses may have a contribution of other unmeasured substances present in sewage (e.g. Bao et al., 2013; GyeduAbabio and Baird, 2006; Todd et al., 2010). Toxicity was already reported as a result from environmental relevant concentrations of pharmaceutical compounds (Bila and Dezotti, 2003; Shareef et al., 2008; Maranho et al., 2015), personal care products (Cortez et al., 2012) and hydrocarbons (Jensen and Sverdrup, 2002), for example, among other sewage components. In addition, interactive effects between metals (Hagopian-Schlekat et al., 2001), and metals and other potentially toxic substances in sediment, such as ammonia (Campos et al., 2016), can not be ruled out.

Whereas Nitokra sp. fecundity was similarly affected at St. 2 and St. 3 compared to St. 1, analysis of nematode and copepods densities exhibited a conspicuous declining gradient, indicating the treatment St. 3 as the most impacted. Accordingly, factor analysis exhibited more evident toxic effects at site 3 , which showed positive scores (i.e. lower values for the biological parameters and higher values for chemical concentrations) for factor 1 already after 5 days of exposure maintaining these positive values after 30 days. Station 2 showed positive score values only after 30 days of exposure. Site 1 , on the other hand, showed better environmental conditions since it showed higher values for the biological parameters and lower values for contaminant concentrations at both exposure periods. These results agree with the inverse gradient of increasing contamination with distance from the outfall observed in the field. Such inverse gradient indicates that precipitation of sewage particles and associated contaminants mainly occur when sewage is mixed with sea water, a phenomenon known as 

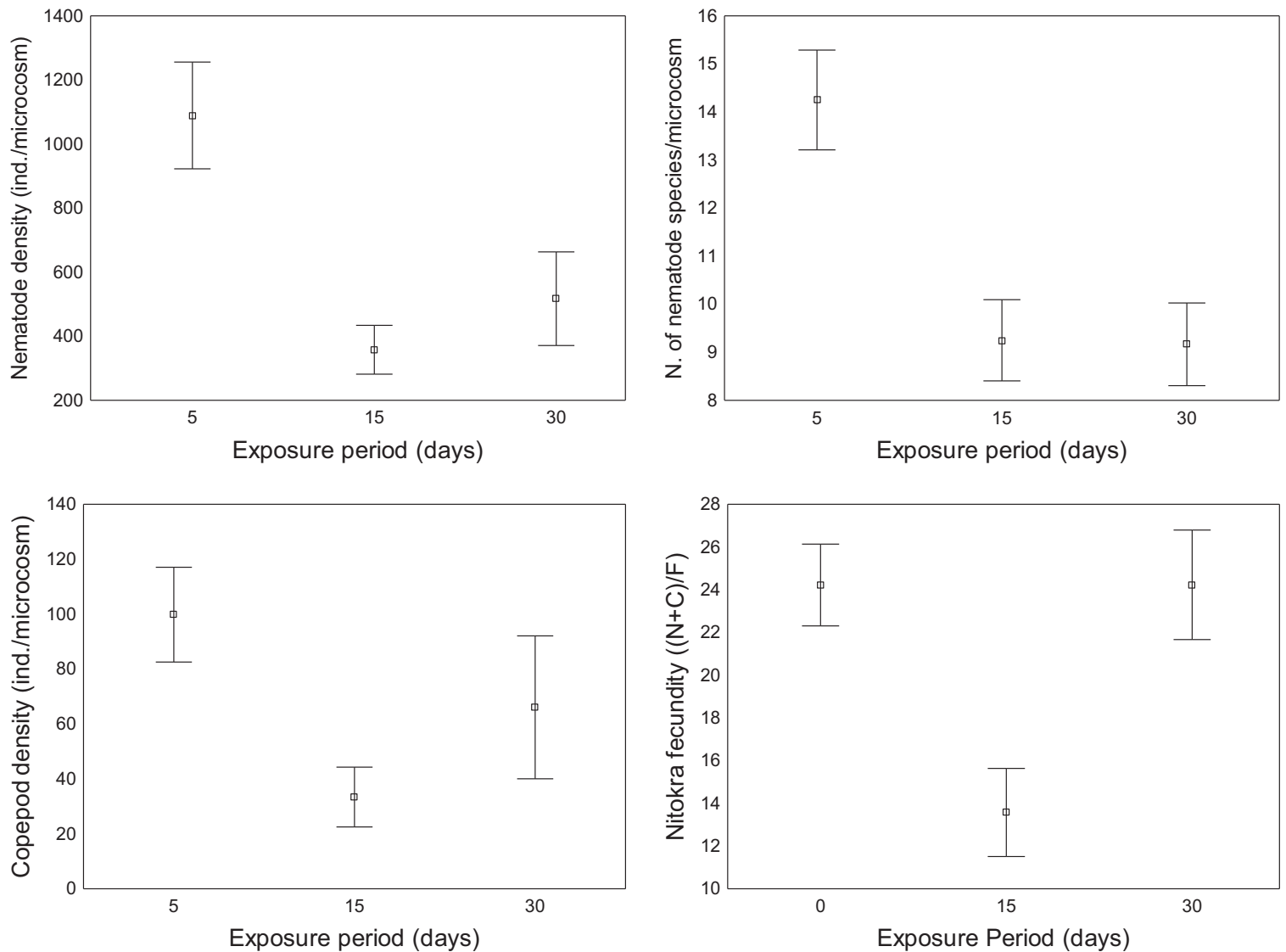

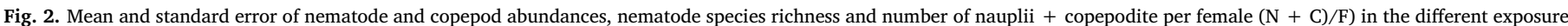
periods.

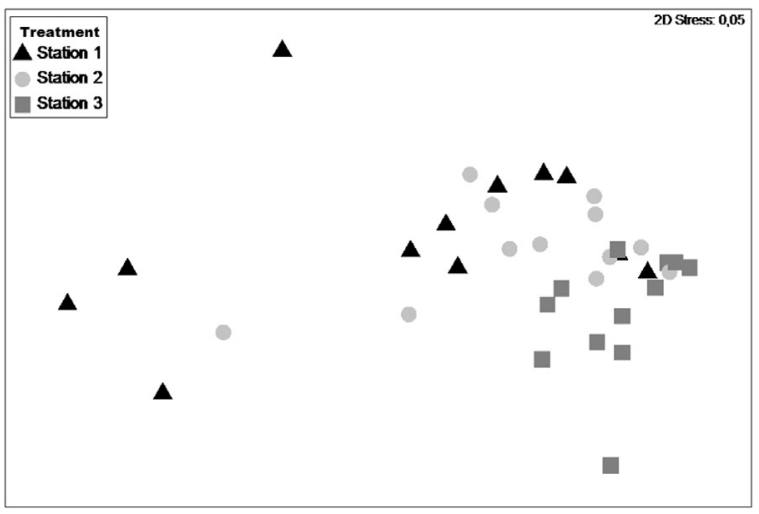

Fig. 3. nMDS ordination from abundances of nematode species in the different sites.

the "salting out effect", which is the decrease of solubility of organic compounds due to the increase of salinity, providing greater precipitation (Qi et al., 2008). Metals may also coagulate, flocculate and precipitate as salinity increases (Chapman and Wang, 2001).

Multivariate community data showed higher differences between treatments St. 1 and St. 3, with St. 2 at an intermediate position between the two, further confirming the contamination gradient. These changes resulted mainly from the decrease in densities of the most abundant species already after 5 days of exposure, which suggests mortality, rather than other sublethal effects, as a cause. Although mortality of the most abundant groups indicates a non species-specific response, we have also detected a differential response of predacious nematodes as a group and SIMPER analysis also indicated lower average abundances of the predator nematode Oncholaimellus sp. 1 at Sts 2 and 3 compared to St. 1 . Such results are particularly interesting
Table 2

Results of PERMANOVA for feeding types of nematode assemblages. EP = Exposure period and Treat $=$ Treatment. Values in bold represent $\mathrm{p}<0.05$.

\begin{tabular}{|c|c|c|c|c|c|}
\hline & $d f$ & MS & Pseudo-F & $P($ perm $)$ & Unique perms \\
\hline \multicolumn{6}{|l|}{$1 A$} \\
\hline Treatment & 2 & 23,014 & 1,376 & 0,282 & 998 \\
\hline Exposure period & 2 & 45,583 & 2,7255 & 0,092 & 999 \\
\hline $\mathrm{EP} \times$ Treat & 4 & 15,599 & 0,93266 & 0,459 & 998 \\
\hline Residue & 27 & 16,725 & & & \\
\hline Total & 35 & & & & \\
\hline \multicolumn{6}{|l|}{$1 B$} \\
\hline Treatment & 2 & $1,3304 \mathrm{E} 5$ & 2,9904 & 0,078 & 999 \\
\hline Exposure period & 2 & 3,932E5 & 8,8383 & 0,003 & 999 \\
\hline $\mathrm{EP} \times$ Treat & 4 & 20310 & 0,45651 & 0,783 & 999 \\
\hline Residue & 27 & 44489 & & & \\
\hline Total & 35 & & & & \\
\hline \multicolumn{6}{|l|}{$2 A$} \\
\hline Treatment & 2 & $4,3068 \mathrm{E} 5$ & 15,59 & 0,001 & 999 \\
\hline Exposure period & 2 & 2,3193E5 & 8,3957 & 0,002 & 999 \\
\hline $\mathrm{EP} \times$ Treat & 4 & 31191 & 1,1291 & 0,369 & 999 \\
\hline Residue & 27 & 27625 & & & \\
\hline Total & 35 & & & & \\
\hline \multicolumn{6}{|l|}{$2 B$} \\
\hline Treatment & 2 & 11948 & 5,2152 & 0,011 & 998 \\
\hline Exposure period & 2 & 50655 & 22,11 & 0,001 & 999 \\
\hline EP $\times$ Treat & 4 & 3951,3 & 1,7247 & 0,181 & 998 \\
\hline Residue & 27 & 2291 & & & \\
\hline Total & 35 & & & & \\
\hline
\end{tabular}

given that the same community has shown a similar response to contamination of sediments by antifouling biocides (Gallucci et al., 2015). This corroborates the group of predacious/omnivorous nematodes as more sensitive to disturbance (Bongers et al., 2001), and also confirms the genus Oncholaimellus as a sensitive genus (Danovaro et al., 1995; 
Table 3

Factor loadings after varimax rotation for the three factors obtained in the FA/PCA. The explained variance of each factor is given in percentage of the total variance in the original data matrix. Marked loadings are $\geq|0.38|$.

\begin{tabular}{|c|c|c|c|}
\hline \multirow[t]{2}{*}{ Variable } & \multicolumn{3}{|c|}{ Factor loadings } \\
\hline & Factor 1 & Factor 2 & Factor 3 \\
\hline Species richness & $-0,58$ & 0,32 & 0,62 \\
\hline Equitativity $\left(\mathrm{J}^{\prime}\right)$ & $-0,19$ & 0,18 & 0,74 \\
\hline Diversity $\left(\mathrm{H}^{\prime}\right)$ & $-0,36$ & 0,28 & 0,79 \\
\hline Nematoda (N) & $-0,86$ & 0,12 & 0,37 \\
\hline Sabatieria sp.1 & 0,14 & 0,25 & 0,65 \\
\hline Oncholaimellus sp.1 & $-0,84$ & 0,37 & 0,14 \\
\hline Nudora sp.1 & $-0,90$ & 0,03 & 0,14 \\
\hline Dichromadora sp.1 & $-0,85$ & 0,08 & 0,19 \\
\hline Pseudosteineria sp.1 & -0.79 & $-0,01$ & 0,20 \\
\hline Copepoda(N) & $-0,82$ & $-0,17$ & 0,29 \\
\hline Nitokrasp. fecundity & $-0,38$ & $-0,15$ & $-0,06$ \\
\hline Chlorophyll & 0,12 & 0,29 & $-0,65$ \\
\hline Pheopigments & $-0,09$ & $-0,56$ & 0,38 \\
\hline Redox & 0,11 & 0,77 & 0,37 \\
\hline Total ammonia & 0,49 & $-0,75$ & $-0,20$ \\
\hline Total nitrogen & $-0,28$ & $-0,68$ & $-0,10$ \\
\hline Total organic carbon & 0,20 & $-0,92$ & $-0,27$ \\
\hline As & 0,09 & 0,66 & 0,02 \\
\hline $\mathrm{Cd}$ & 0,43 & $-0,82$ & $-0,24$ \\
\hline $\mathrm{Cu}$ & 0,60 & $-0,51$ & 0,34 \\
\hline $\mathrm{Cr}$ & 0,69 & 0,15 & 0,18 \\
\hline $\mathrm{Hg}$ & $-0,72$ & 0,24 & 0,28 \\
\hline $\mathrm{Ni}$ & 0,63 & $-0,74$ & 0,06 \\
\hline $\mathrm{Pb}$ & 0,56 & $-0,38$ & 0,16 \\
\hline $\mathrm{Zn}$ & 0,80 & $-0,47$ & $-0,14$ \\
\hline Surfactants & 0,77 & 0,17 & $-0,11$ \\
\hline Explained variance & $41.92 \%$ & $16.84 \%$ & $10.53 \%$ \\
\hline
\end{tabular}

Gallucci et al., 2015). Whereas the reasons for higher sensitivity of predacious nematodes to disturbance might be due to their longer-lived life strategy (Bongers et al., 2001), we believe that regarding contamination, the short-term response directed to this functional group might be due to their smooth cuticle, which is more permeable than more ornamented cuticles (Fonseca and Fehlauer-Ale, 2012), therefore being a major route for uptake of contaminants (Howell, 1983; Kammenga et al., 1994).

In addition to mortality of some nematode populations, we have also observed the increase in densities of the opportunistic species Sabatieria sp.1. at treatment St. 3. Such increase is probably an indirect effect of contamination which has caused the death of abundant species living space/resource available for the opportunistic species to flourish. This genus is known as having a direct positive relationship with anthropogenic disturbance (Schratzberger et al., 2009), being highly adapted to fit into new habitats, conditions or resources (Heip et al., 1985) and an indicator of a poor ecological quality status due to its tolerance to pollution (Austen and Somerfield, 1997; Moreno et al., 2011; Soetaert et al., 1995). F3 in the multivariate analysis further illustrates possible indirect effects of contamination. Loadings for F3 showed a positive relationship between species richness, diversity, equitability and densities of Sabatieria sp. The factor scores showed that these values were particularly high for the treatment St.3. This result indicates that the lower dominance of the typically most abundant species in this treatment has indirectly caused an increase in diversity and equitability indices, at the same time it has allowed the increase in abundance of a tolerant and opportunistic species.

Concerning the exposure period, there was a decrease in nematode diversity and abundance after 15 days, regardless of treatment. Although this could be an effect of the enclosure in the microcosm experiment (Gallucci et al., 2015; Schratzberger et al., 2002), it is important to note that Nitokra sp. fecundity test also showed significantly lower fecundity rates in sediments which had been exposed for 15 days, independently of the treatment. Such results suggest that toxicity has
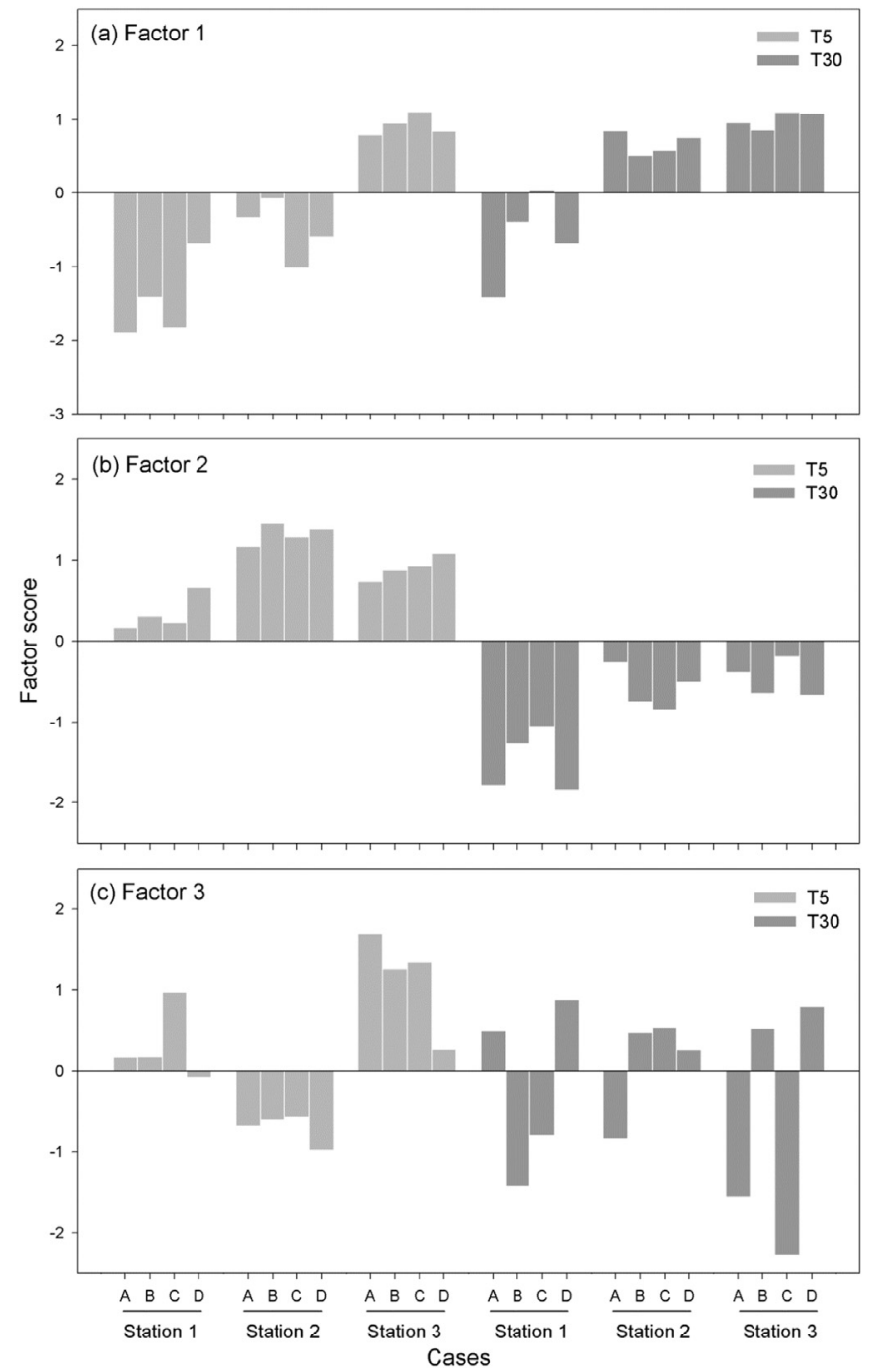

Fig. 4. Factor loadings after varimax rotation for the three factors obtained in the FA/ PCA.

increased during the exposure period and lower meiofauna densities and diversity are probably a result of this increased toxicity in all treatments rather than a microcosm effect.

The increased toxicity exhibited by the sediments at 15-day exposure reinforces that unmeasured chemicals, as the PPCPs, may be the cause of the observed toxicity. It is known that some organic pollutants, including PPCPs, are degraded into substances with higher toxicity than the parent compound. Köhler et al. (2006) observed increased ecotoxicity of an industrial wastewater following a reduction in the organic pollutants load after biological treatment, suggesting a transformation of the parental pollutant into more toxic by-products. Regarding PPCPs, Triclosan, which has shown to exert toxicity effects at environmentally relevant concentrations as the parental compound (Cortez et al., 2012), is also converted by photodegradation into toxic substances such as dioxins and furans (Kanetoshi et al., 1987; Latch et al., 2003). Other pharmaceuticals compounds which are known to produce metabolites that may be toxic in the environment include the antibiotics cefazolin and cephapirin (Wang and Lin, 2012), acetylsalicylic acid, carbamazepine, diclofenac, sulfonamides, among others (Celiz et al., 2009).

The integration of biotic and environmental data also showed, in factor 2, a clear separation of the exposure periods. After 30 days of exposure, redox values and ammonia concentrations were generally higher when compared to 5 days. This was true for sites 1,2 and 3 which showed negative scores at 5 days and positive scores after 30 
days. This is probably a result of microbial degradation processes and accumulated nitrogen excretion by the test-organisms in the microcosms. Despite the potential of those changes to affect the test-organisms and the outcome of the test, changes were similar to all treatments excluding the possibility of these being an indirect effect of the contamination.

\section{Conclusion}

Both single-species test and community level microcosm approaches agreed in detecting differences in toxicity between the less and most contaminated sites. However, only data derived from community analysis detected the expected differences in the gradient of contamination. These results indicate that the microcosm approach using natural communities was more sensitive to the detection of more subtle impacts when compared to the single-species fecundity approach. In addition to information about toxicity, the community level microcosm experiments gave also indications about sensitive and tolerant species, indirect ecological effects, as well as raised hypothesis about contamination routes to be tested. Considering the importance of freeliving marine nematodes for benthic ecosystems, the microcosm approach using natural meiobenthic communities might be a valuable addition as a higher tier approach in ecological risk assessment, providing highly relevant ecological information on the toxicity of contaminated sediments.

\section{Acknowledgements}

We are grateful to Paulo C. Lana for valuable comments on an earlier version of the manuscript. We also thank Felipe Gusmao for revising the English. This article resulted from a master thesis from the 'Programa de Pós Graduação em Sistemas Costeiros e Oceânicos (PGSISCO) offered by Universidade Federal do Paraná (UFPR). A.C.C.S. was supported by Coordenação de Aperfeiçoamento de Pessoal de Nível Superior (CAPES). R.B.C. thanks to CNPq for the grant conceded (CNPq 308079/2015-9). The study was supported by Fundação de Amparo à Pesquisa do Estado de São Paulo (FAPESP) under the project 2009/ 11808-3.

\section{Appendix A. Supporting information}

Supplementary data associated with this article can be found in the online version at http://dx.doi.org/10.1016/j.ecoenv.2017.09.040.

\section{References}

Anderson, M.J., 2001. A new method for non-parametric multivariate analysis of variance. Austral Ecol. 26, 32-46.

Anderson, M.J., Gorley, R.N., Clarke, K.R., 2008. PERMANOVA + for PRIMER: Guide to Software and Statistical Methods.

Anderson, M.J., Crist, T.O., Chase, J.M., Vellend, M., Inouye, B.D., Freestone, A.L., Sanders, N.J., Cornell, H.V., Comita, L.S., Davies, K.F., Harrison, S.P., Kraft, N.J.B., Stegen, J.C., Swenson, N.G., 2011. Navigating the multiple meanings of $\beta$ diversity: a roadmap for the practicing ecologist. Ecol. Lett. 14, 19-28. http://dx.doi.org/10. 1111/j.1461-0248.2010.01552.x.

Austen, M.C., McEvoy, A.J., 1997. Experimental effects of tributyltin (TBT) contaminated sediment on a range of meiobenthic communities. Environ. Poll. 96, 435-444.

Austen, M.C., Somerfield, P.J., 1997. A community level sediment bioassay applied to an estuarine heavy metal gradient. Mar. Environ. Res. 43, 315-328.

Austen, M.C., McEvoy, A.J., Warwick, R.M., 1994. The specificity of meiobenthic community responses to different pollutants: results from microcosm experiments. Mar. Pollut. Bull. 28, 557-563.

Bao, V.W.W., Leung, K.M.Y., Lui, G.C.S., Lam, M.H.W., 2013. Acute and chronic toxicities of Irgarol alone and in combination with copper to the marine copepod Tigriopus japonicus. Chemosphere 90, 1140-1148. http://dx.doi.org/10.1016/j.chemosphere. 2012.09.022.

Bila, D.M., Dezotti, M., 2003. Pharmaceutical drugs in the environment. Quim. Nova 26. http://dx.doi.org/10.1590/S0100-40422003000400015.

Bonaglia, S., Nascimento, F.J.A., Bartoli, M., Klawonn, I., Brüchert, V., 2014. Meiofauna increases bacterial denitrification in marine sediments. Nat. Commun. 5. http://dx. doi.org/10.1038/ncomms6133.
Bongers, T., Ilieva-Makulec, K., Ekschmitt, K., 2001. Acute sensitivity of nematode taxa to CuSO4 and relationships with feeding-type and life-history classification. Environ. Toxicol. Chem. 20, 1511-1516. http://dx.doi.org/10.1002/etc.5620200714.

Cairns, J., Pratt, J.R., 1993. Trends in ectoxicology. Sci. Total Environ. 134, 7-22. http:// dx.doi.org/10.1016/S0048-9697(05)80003-8.

Campos, B.G., Cruz, A.C.F., Buruaem, L.M., Rodrigues, A.P.C., Machado, W.T.V., Abessa, D.M.S., 2016. Using a tiered approach based on ecotoxicological techniques to assess the ecological risk of contamination in a subtropical estuarine protected area. Sci. Total Environ. 544, 564-573.

Carr, R.S., Chapman, D.C., Howard, C.L., Biedenbach, J.M., 1996. Sediment quality triad assessment survey of the Galveston Bay, Texas system. Ecotoxicology 364, 341-364.

CCME, 2001. Canadian Sediment Quality Guidelines for the Protection of Aquatic Life.

Celiz, M.D., Tso, J., Aga, D.S., 2009. Pharmaceutical metabolites in the environment: analytical challenges and ecological risks. Environ. Toxicol. Chem. SETAC 28, 2473-2484.

Chapman, P.M., 2002. Integrating toxicology and ecology: putting the "eco" into ecotoxicology. Mar. Pollut. Bull. 44, 7-15. http://dx.doi.org/10.1016/S0025-326X(01) 00253-3.

Chapman, P.M., Hollert, H., 2006. Should the sediment quality triad become a tetrad, a pentad, or possibly even a hexad? J. Soils Sediment. 6, 4-8. http://dx.doi.org/10. 1065/jss2006.01.152.

Chapman, P.M., Wang, F., 2001. Assessing sediment contamination in estuaries. Environ. Toxicol. Chem. 1, 3-22.

Choueri, R.B., Cesar, A., Torres, R.J., Abessa, D.M.S., Morais, R.D., Pereira, C.D.S., Nascimento, M.R.L., Mozeto, A.A., Riba, I., DelValls, T.A., 2009. Integrated sediment quality assessment in Paranaguá Estuarine system, Southern Brazil. Ecotoxicol. Environ. Saf. 72, 1824-1831.

Choueri, R.B., Cesar, A., Abessa, D.M.S., Torres, R.J., Riba, I., Pereira, C.D.S., Nascimento, M.R.L., Morais, R.D., Mozeto, A.A., DelValls, T.A., 2010. Harmonised framework for ecological risk assessment of sediments from ports and estuarine zones of North and South Atlantic. Ecotoxicology 19, 678-696.

Clarke, K., Ainsworth, M., 1993. A method of linking multivariate community structure to environmental variables. Mar. Ecol. Prog. Ser. 92, 205-219.

Clarke, K.R., Gorley, R.N., 2006. PRIMER v6: User Manual/Tutorial.

Coomans, A., 2000. Nematode systematics: past, present and future. Nematology 2, 3-7.

Cortez, F.S., Pereira, C.D.S., Santos, A.R., Cesar, A., Choueri, R.B., Martini, G.D.A., Bohrer-morel, M.B., 2012. Biological effects of environmentally relevant concentrations of the pharmaceutical Triclosan in the marine mussel Perna perna (Linnaeus, 1758). Environ. Pollut. 168, 145-150. http://dx.doi.org/10.1016/j.envpol.2012.04. 024 .

Danovaro, R., Fabiano, M., Vincx, M., 1995. Meiofauna response to the Agip Abruzzo oil spill in subtidal sediments of the Ligurian Sea. Mar. Pollut. Bull. 30, 133-145.

EMBRAPA, 1997. Manual de Métodos de Análise de Solo. Rio de Janeiro.

Environmental Protection Agency, 1996. Method 3050B: Acid Digestion of Sediments, Sludges, and Soils.

Environmental Protection Agency, 2001. Methods for Collection, Storage and Manipulation of Sediments for Chemical and Toxicological Analyses: Technical Manual. Washington, DC.

Environmental Protection Agency, 2007a. Method 6010C: Inductively Coupled PlasmaAtomic Emission Spectrometry 1-34.

Environmental Protection Agency, 2007b. Method 7471B: Mercury in Solid or Semisolid Waste (manual cold-vapor technique).

Fonseca, G., Fehlauer-Ale, K., 2012. Three in one: fixing marine nematodes for ecological, molecular, and morphological studies. Limnol. Oceanogr. 10, 516-523. http://dx.doi. org/10.4319/lom.2012.10.516.

Gallucci, F., Castro, I.B., de, Perina, F.C., Abessa, D.M., de, S., Teixeira, A., de, P., 2015 Ecological effects of Irgarol 1051 and Diuron on a coastal meiobenthic community: a laboratory microcosm experiment. Ecol. Indic. 58, 21-31.

Gyedu-Ababio, T.K., Baird, D., 2006. Response of meiofauna and nematode communities to increased levels of contaminants in a laboratory microcosm experiment. Ecotoxicol. Environ. Saf. 63, 443-450.

Hagopian-Schlekat, T., Chandler, G.T., Shaw, T.J., 2001. Acute toxicity of five sedimentassociated metals, individually and in a mixture, to the estuarine meiobenthic harpacticoid copepod Amphiascus tenuiremis. Mar. Environ. Res. 51, 247-264.

Heip, C., Vincx, M., Vranken, G., 1985. The ecology of marine nematodes. Oceanogr. Mar. Biol. Ann. Rev. 23, 399-489.

Höss, S., Reiffa, N., Nguyenc, H.T., Jehlec, J.A., Hermes, H., Traunspurger, W., 2014 Small-scale microcosms to detect chemical induced changes in soil nematode communities - effects of crystal proteins and Bt-maize plant material. Sci. Total Environ. $472,662-671$.

Howell, R., 1983. Heavy metals in marine nematodes: uptake, tissue distribution and loss of copper and zinc. Mar. Pollut. Bull. 14, 263-268.

Hubas, C., Sachidhanandam, C., Rybarczyk, H., Lubarsky, H.V., Rigaux, A., Moens, T. Paterson, D.M., 2010. Bacterivorous nematodes stimulate microbial growth and exopolymer production in marine sediment microcosms. Mar. Ecol. Prog. Ser. 419, 85-94.

Jensen, J., 2004. Ecotoxicological Effect Assessment and Risk Characterisation of Selected Contaminants in Sewage Sludge. Danish University of Pharmaceutical Sciences, Department of Analytical Chemistry.

Jensen, J., Sverdrup, L.E., 2002. Joint toxicity of linear alkylbenzene sulfonates and pyrene on Folsomia fimetaria. Ecotoxicol. Environ. Saf. 52, 75-81. http://dx.doi.org/ 10.1006/eesa.2002.2149.

Kammenga, J.E., Vangestel, C.A.M., Bakker, J., 1994. Patterns of sensitivity to cadmium and pentachlorophenol among nematode species from different taxonomic and ecological groups. Arch. Environ. Contam. Toxicol. 27, 88-94.

Kanetoshi, A., Ogawa, H., Katsura, E., Kaneshima, H., 1987. Chlorination of Irgasan 
DP300 and formation of dioxins from its chlorinated derivates. J. Chromatogr. A 389, 139-153.

Kimball, K.D., Levin, S.A., 1985. Limitations of laboratory bioassays: the need for ecosystem-level testing. Bioscience 35, 165-171.

Köhler, A., Hellweg, S., Escher, B., Hungerbuhler, K., 2006. Organic pollutant removal versus toxicity reduction in industrial wastewater treatment: the example of wastewater from fluorescent whitening agent production. Environ. Sci. Technol. 40, 3340-3395.

Krull, M., Abessa, D.M.S., Hatje, V., Barros, F., 2014. Integrated assessment of metal contamination in sediments from two tropical estuaries. Ecotoxicol. Environ. Saf. 106, 195-203.

Lambshead, P.J.D., Boucher, G., 2003. Marine nematode deep-sea biodiversity - hyperdiverse or hype? J. Biogeogr. 30, 475-485. http://dx.doi.org/10.1046/j.1365 2699.2003.00843.x.

Latch, D.E., Packer, J.L., Arnold, W.A., McNeill, K., 2003. Photochemical conversion of triclosan to 2,8 - dichlorodibenzo-p-dioxin in aqueous solution. J. Photochem. Photobiol. A Chem. 158, 63-66.

Long, E.R., Chapman, P.M., 1985. A sediment quality triad: measures of sediment contamination, toxicity and infaunal community composition in Puget Sound. Mar. Pollut. Bull. 16, 405-415. http://dx.doi.org/10.1016/0025-326X(85)90290-5.

Lorenzen, C.J., 1967. Determination of chlorophyll and pheo-pigments: spectrophotometric equations. Limnol. Oceanogr. 12, 343-346.

Lotufo, G.R., Abessa, D.M.S., 2002. Testes de toxicidade com sedimentos total e água intersticial estuarinos utilizando copépodos bentônicos. In: Nascimento, I.A., Sousa, E.C.P.M., Nipper., M.G. (Eds.), Métodos Em Ecotoxicologia Marinha: Aplicações No Brasil. Artes Gráficas e Indú, São Paulo.

Maranho, L.A., Garrido-Pérez, M.C., Baena-Nogueras, R.M., Lara-Martín, P.A., Antón Martín, R., DelValls, T.A., Martín-Díaz, M.L., 2015. Are WWTPs effluents responsible for acute toxicity? Seasonal variations of sediment quality at the Bay of Cádiz (SW, Spain). Ecotoxicol. 24 (2), 368-380.

Millward, R.N., Carman, K.R., Fleeger, J.W., Gambrell, R.P., Portierc, R., 2004. Mixtures of metals and hydrocarbons elicit complex responses by a benthic invertebrate community. J. Exp. Mar. Biol. Ecol. 310, 115-130.

Moreno, M., Semprucci, F., Vezzulli, L., Balsamo, M., Fabiano, M., Albertelli, G., 2011. The use of nematodes in assessing ecological quality status in the Mediterranean coastal ecosystems. Ecol. Indic. 11, 328-336. http://dx.doi.org/10.1016/j.ecolind. 2010.05.011.

Qi, D., Kang, X., Chen, L., Zhang, Y., Wei, H., Gu, Z., 2008. Electrospun polymer nanofibers as a solid-phase extraction sorbent for the determination of trace pollutants in environmental water. Anal. Bioanal. Chem. 390, 929-938. http://dx.doi.org/10. 1007/s00216-007-1747-4.

Rachid, B.R.F., 2002. Avaliação ecotoxicológica dos efluentes domésticos lançados pelos sistemas de disposição oceânica da Baixada Santista. Doctorate Thesys, Universidade de São Paulo, Instituto Oceanográfico, São Paulo, pp. 286.

Rodgers-Gray, T.P., Jobling, S., Morris, S., Kelly, C., Kirby, S., Janbakhsh, A., Waldock, M.J., Sumpter, J.P., Tyler, C.R., 2000. Long-term temporal changes in the estrogenic composition of treated sewage effluent and its biological effects on fish. Environ. Sci. Technol. 34, 1521-1528.

Rohr, J.R., Salice, C.J., Nisbet, R.M., 2016. The pros and cons of ecological risk assessment based on data from different levels of biological organization. Crit. Rev. Toxicol. 46, 756-784.

SCENIHR, SCCS, SCHER, 2013. Adressing the New Challenges for Risk Assessment.

Schratzberger, M., Rees, H.L., Boyd, S.E., 2000. Effects of simulated deposition of dredged material on structure of nematode assemblages-the role of contamination. Mar. Biol.

Schratzberger, M., Wall, C.M., Reynolds, W.J., Reed, J., Waldock, M.J., 2002. Effects of paint-derived tributyltin on structure of estuarine nematode assemblages in experimental microcosms. J. Exp. Mar. Biol. Ecol. 272, 217-235.

Schratzberger, M., Lampadariou, N., Somerfield, P.J., Vandepitte, L., Vanden Berghe, E., 2009. The impact of seabed disturbance on nematode communities: linking field and laboratory observations. Mar. Biol. 156, 709-724. http://dx.doi.org/10.1007/ s00227-008-1122-9.

Shareef, A., Kookana, R., Kumar, A., Tjandraatmadja, G., 2008. Sources of Emerging Organic Contaminants in Domestic Wastewater an Assessment Based on Literature Review.

Soetaert, K., Vincx, M., Wittoeck, J., Tulkens, M., 1995. Meiobenthic distribution and nematode community structure in five European estuaries. Hydrobiologia 311, 185-206. http://dx.doi.org/10.1007/BF00008580.

Standard Methods, 2005. 5540D, 5540 Surfactants.

Standard Methods Online, 1992. 4500-NH3 D. Ammonia-Selective Electrode Method.

Tjandraatmadja, G., Diaper, C., Gozukara, Y., Burch, L., Sheedy, C., Price, G., 2008. Sources of Critical Contaminants in Domestic Wastewater: Contaminant Contribution from Household Products.

Todd, P.A., Ong, X., Chou, L.M., 2010. Impacts of pollution on marine life in Southeast Asia. Biodivers. Conserv. 19, 1063-1082. http://dx.doi.org/10.1007/s10531-0109778-0.

Van den Brink, P.J., Tarazona, J.V., Solomon, K.R., Knacker, T., Van den Brink, N.W., Brock, T.C.M., Hoogland, J.P., 2005. The use of terrestrial and aquatic microcosms and mesocosms for the ecological risk assessment of veterinary medicinal products. Environ. Toxicol. Chem. 24, 820-829. http://dx.doi.org/10.1897/04-268R.1.

Vighi, M., Villa, S., 2013. Ecotoxicology: the challenges for the 21st century. Toxics 1 , 18-35. http://dx.doi.org/10.3390/toxics1010018.

Wang, X.-H., Lin, A.Y.-C., 2012. Phototransformation of cephalosporin antibiotics in an aqueous environment results in higher toxicity. Environ. Sci. Technol. 46, 12417-12426.

Warwick, R.M., Platt, H.M., Somerfield, P.J., 1998. Free-living Marine Nematodes. Part III. British Monhysterids. Synopses of the British Fauna (New Series). Field Studies Council, Shrewsbury.

Wieser, W., 1953. Die Beziehung zwischen Mundhöhlengestalt, Ernährungsweise und Vorkommen bei freilebenden marinen nematoden: Eine okologisch- morphologische studie. Ark. Zool. 4, 439-484.

Woodward, G., 2010. Integrative ecology: from molecules to ecosystems. Advances in Ecological Research. Academic Press, London. 43. 